\title{
Ozone in Dentistry: A Review
}

\section{VINIT KUMAR*1, CHANDNI ${ }^{2}$ (D)} dental problems due to its atraumatic, biologically based treatment. This review explores the use of ozone in dentistry.

\section{KEYWORDS: Ozone, Dental Caries, Osteonecrosis, Root Canal Treatment}

\section{INTRODUCTION}

Ozone is a blue gas naturally present in stratosphere. It is made up of three oxygen atoms that give unstable oxygen gas which has highest oxidation potential. The highest oxidation potential of ozone leads to lyses of the outer membrane of the micro-organisms and therefore used in dentistry. The word ozone originates from the Greek word "ozein", which means odor and was first used in 1840 by German chemist Christian Friedrich Schonbein, 'the father of ozone therapy'. ${ }^{1}$

Ozone was first of all used by E.A. Fisch in 1930's to treat dental problems. ${ }^{2}$ However, at that time ozone resistant materials like dacron and teflon were not available which led to difficulty in use of ozone at that time. Manufacturing of ozone resistant material began in 1950, which boosted the use of ozone in dentistry. In 1957, Joachim Hänsler, a German physicist and Hans Wolff, a German physician developed ozone generator for medical use.

However, it was only at the end of 1980s, medical ozone became subject of dental research and practice. Subsequent to this, it was used increasingly for medical and dental purposes. ${ }^{3}$

\section{OZONE GENERATING SYSTEM}

There are three ozone generating systems ${ }^{4}$

1.UV system: In this system, a UV Lamp at $185 \mathrm{~nm}$ creates ozone from oxygen by disrupting the oxygen molecule and splitting it into two oxygen atoms. These two oxygen atoms attempt to attach to each other to form an oxygen molecule. This attachment of third oxygen molecule leads to formation of ozone.

2. Cold plasma system: Cold plasma is a gas which is partially ionized and created at room temperature or lower. Ionization of pure oxygen takes place between two electrodes, which are separated by a dielectric barrier. When the plasma is formed oxygen molecules split into single oxygen atom which then recombines with oxygen and forms ozone.

3. Corona discharge system: In this method air is channelled into corona discharge tube in which plasma is created by applying a strong electric field. This plasma then dissociates into single oxygen atoms, which then are free to recombine with oxygen molecule to form ozone. The handling of this design is easy and the ozone production rate can be controlled, hence most commonly used in the medical and dental fields.

\section{ROUTES OF OZONE ADMINISTRATION}

1. Gaseous form: Ozone in gaseous form is used to treat various dental problems. Gaseous ozone is administered either topically or by sealed suction system. It can be used for the treatment of dental caries and as dental disinfectant. Main problem with system is toxicity, when inhaled. ${ }^{5}$ It is a non-invasive therapy for treatment of dental caries and may be used as a disinfectant before the placement of a direct restoration.

2. Ozonated water: Hutch et al. evaluated the biocompatibility of aqueous form of ozone and reported 
that ozone is potent antiseptic agent. ${ }^{6}$ It is less cytotoxic than gaseous form. It is effective against both gram positive and negative microorganisms. Ozone water accelerates healing of mucosa when applied daily. ${ }^{7}$

3. Ozonized oil: It is also as effective as gaseous and aqueous form. It is effective against Streptococci, Enterococci, Staphylococci, Pseudomonas, Escherichia coli and is used for the cure of fungal infections. ${ }^{8}$ Commercially, it is available as Oleozone and Bioperoxoil.

\section{APPLICATIONS OF OZONE IN DENTISTRY}

Ozone is a very good alternative and/or an additional disinfectant to standard antiseptics due to its undisputed disinfection power over other antiseptics. According to Krammer, 9 a German dentist, aqueous ozone can be used:

1. Treating Caries: Ozone helps in treating dental caries. It leads to re-mineralization of enamel and prevents caries progression. It also leads to destruction of all kind of micro-organisms in oral cavity and their waste acidic by products. Reversal is shown in non cavitated root caries. ${ }^{10}$

2. Ozone in Endodontics: Often caries lesion leads to pulp infection due to ingress of micro-organisms. Tooth root has multiple lateral canals and a periapical space that can all be inhabited by pathogenic bacteria. Sodium hypochloride, the main irrigant in root canal treatment is also not able to reach all the canals and especially in lateral canals, which if left unclean act as a potent source of root canal treatment failure, studies show that ozone is more potent than hypo in these cases and clean effective lateral canals and also more effective against Enterococcus faecalis, major causative factor in endodontic disease which is particularly resistant to sodium hypochlorite. Ozone also helps in reducing the number of microorganisms in the periapical region and helps in healing of the osseous structures. ${ }^{11,12}$

3. Managing Periodontal Infection: Periodontal (gum) disease is most commonly associated with loosening and loss of teeth. Ozone helps in this condition. Firstly, the deep pockets are irrigated around the roots using ozonated water during debridement processes, and then insufflate the deep, infected crevices with ozone gas using fine cannulae, followed by placement of ozonated oils for longer term disinfection. Patients may also be given their own supply of ozonated oils to place into hard-to-reach areas on a daily basis.
And, again, tray insufflations are often recommended as a periodic preventive regimen. Ozonated water inhibits the accumulation of experimental dental plaque in vitro. ${ }^{13}$

4. Viral and Fungal Infections: Ozone reduces the load of virus and fungus in oral infection. Both gaseous and aqueous forms are effective in reducing the viral infection.

5. Sinusitis and Temporomandibular Joint Dysfunction: Sinusitis is an infection of the paranasal sinuses due to bacteria, virus, fungus and allergens. Ozone Therapy can neutralize toxins and impurities in the body, rid the body of carbon monoxide and combat allergy causing substances. Ozone Therapy can also kill viruses \& bacteria in the body, relieve fever, increase white blood cell count, boost the immune system and fight bronchitis \& asthma. Petrov GM et al. in a controllable study showed early healing in patients treated with $0.9 \%$ solution of sodium chloride, saturated with ozone. ${ }^{14}$

Daif ET documented that patients who received ozone gas injections into the superior joint space either completely recovered or improved early in comparison to those who took non-steroidal anti-inflammatory drugs and muscle relaxants. ${ }^{15}$

6. Bisphosphonate Lesion Treatment: Osteonecrotic lesions mostly of the mandible are always a great challenge to treat and even more challenging in patients on bisphosphonate medications. Many of these are secondary to infections or tooth extractions on patients who have received significant doses of bisphosphonate medications. Ozone seems well suited to resolution of these problematic lesions that otherwise require multiple surgical interventions and treatment with exotic and very costly antibiotics.

7. Uses in Oral Surgery: Ozone is used from simple tooth extraction to large surgical procedures. Ozone increases oxygen release in the tissue by erythrocytes that leads to faster healing of wounds. It also leads to vasodilation and increase blood supply to the ischemic areas that leads to faster healing. Kazancioglu et al. concluded that ozone application reduces postoperative pain after $3^{\text {rd }}$ molar surgery. ${ }^{16}$ Ozone has antihypoxia and haemostatic properties that overcome the use of hyperbaric oxygen in osteomyelitis. Studies showed that ozone provides favorable environment by reducing inflammation and necrosis. ${ }^{17}$ 
8. Ozone and Dental Unit Water Lines: Water lines are one of the most vulnerable and most neglected site in dental clinic that harbor large number of microorganisms. Condition becomes worse in stagnant water lines. Splatters from these pipelines due to back flow of water lead to infection in health care workers. Szymanska and others identified moulds, fungus and other opportunistic pathogens from the dental water lines sample. ${ }^{18}$

Ozone in gaseous or aqueous form can be effectively used for the sanitization of the dental water lines/units. Kohno $\mathrm{S}$ et al. showed reduction of microorganisms in the dental water units/pipes and they advocated developing a design in dental water lines that incorporates automatic devices to clean water line units. ${ }^{19}$ Studies show $55 \%$ reduction of microorganisms from water line units by ozone. ${ }^{20}$

\section{MECHANISM OF ACTION}

Ozone therapy has a wide range of applications in treating various diseases owing to its unique properties including antimicrobial, immunostimulant, analgesic, anti-hypnotic, detoxicating, bioenergetic and biosynthetic actions.

1. Anti-Microbial Effect: Ozone has high oxidation potential. After entering the cell, it oxidized all essential components of the cells and leads to lyses of the cell/bacteria. It also inhibits the cell growth of the fungus $^{21}$ and inhibits growth of the virus by damaging the virus capsid. ${ }^{22}$ Ozone in concentration of o.1ppm is effective for inactivating the growth of the bacteria. ${ }^{23}$ Ozone therapy increases oxygen perfusion to the tissues by the erythrocytes due to activation of 2,3diphosphoglycerate which in turn is activated due to increase in the red blood cell glycolysis rate. Ozone also stimulates production of ATP via Krebs cycle by enhancing oxidative carboxylation of pyruvate. It also causes a significant reduction in NADH and helps to oxidize cytochrome $\mathrm{C}$. Ozone also stimulates the production of enzymes which act as free radical scavengers and cell-wall protectors: glutathione peroxidase, catalase and superoxide dismutase and prostacycline, a vasodilator. ${ }^{24}$

2. Activation of Immune System: Ozone activates the cascade of immunological reactions by increasing the production of interferon, tumor necrosis factor and interleukin-2 at concentration between 30 and 55 $\lg /$ cc. $^{25}$

\section{ADVANTAGES OF USING OZONE}

It is a safe and painless procedure.

\section{DISADVANTAGES OF USING OZONE}

The main disadvantage of the ozone is the instability and toxicity if its level increases above $.0007 \%$ per application.

Ozone Toxicity: Although ozone is safe and good alternative in dentistry, but main side effect is toxicity. Ozone is safe at .05ppm for 8 hours, above this, it leads to toxicity when inhaled. A maximum concentration of ozone in oral cavity amounts to o.o1 ppm, during ozone therapy. Studies showed that the bronchial-pulmonary system is very sensitive to ozone and this gas should never be inhaled. ${ }^{26}$ The respiratory tract lining is very thin and contains a minimal amount of antioxidants that make mucosal cells extremely vulnerable to oxidation. Pulmonary embolism occurs during direct intravenous administration of $\mathrm{O}_{2} / \mathrm{O}_{3}$, an application prohibited by the European Society of Ozone therapy since $1983 .{ }^{27}$ Some other minor side effects are epiphora and upper respiratory irritation, rhinitis, cough, headache, occasional nausea, and vomiting. To prevent Ozone intoxication, patient is placed in supine position and humid oxygen is given. Vitamin $\mathrm{E}$ and $\mathrm{C}$ are prescribed. ${ }^{8}$

\section{CONTRAINDICATIONS WHILE USING OZONE}

Acute alcohol intoxication, pregnancy, severe anemia, recent myocardial infarction, hyperthyroidism, active hemorrhage, and thrombocytopenia.

\section{CONCLUSION}

Ozone is a new tool for the treatment of the patients in dentistry. It is potent agent for removing microorganisms from oral cavity and sanitization of the dental waterline units. Main advantage with ozone is that it is biocompatible and side effects are less when given in proper ratio and judiciously. In dentistry it is used in three forms viz. gaseous, aqueous and oil form. In dentistry it is used for irrigation of root canals in root canal treatment to remove microorganisms that are resistant to hypochloride solution, mostly used to clean root canals, also used in the treatment of periodontal diseases, as an alternative to hyperbaric oxygen in osteomyelitis, also used to remove/ arrest the progression of the dental caries. It is also effective in sanitization of the dental water units. 
It is a good and new weapon for the dentists. Like every medicine ozone also has few limitations/ side effects. Future of dentistry is bright with ozone if used judiciously but still more studies are needed in field of ozone to make it safer and more efficient. Present laboratory studies show brighter future of the ozone in dentistry and medicine.

\section{REFERENCES}

1. Seidler V, Linetskiy I, Hubalkova H, Stankova H, Smucler R, Mazanek J. Ozone and its usage in general medicine and dentistry. Prague Med Rep. 2008;109(1):513.

2. Bayson A, Lynch E. Antimicrobial effects of ozone on caries. In: Lynch E, editor. Ozone: the revolution in dentistry. London Quintessence Publishing Co.; 2004. p. $165-72$.

3. Fish E. Apparatus for the Production and Use of Ozone in Therapeutics. United States Patent 2,054,367; 1936.

4. Nogales CG, Ferrari PH, Kantorovich EO, Lage Marques JL. Ozone therapy in medicine and dentistry. J Contemp Dent Pract. 2008;9:75-84. https://doi.org/10.5005/jcdp-9-4-75

5. Gupta S, Deepa D. Application of ozone therapy in dentistry. J Oral Res. 2016;8:86-91. https://doi.org/ 10.4103/2249-4987.192243

6. Huth KC, Jakob FM, Saugel B, Cappello C, Paschos E, Hollweck R, et al. Effect of ozone on oral cells compared with established antimicrobials. Eur J Oral Sci. 2006;114:435-40.

7. Filippi A. The influence of ozonised water on the epithelial wound healing process in the oral cavity. Clinic of Oral Surgery, Radiology and Oral Medicine, University of Basel, Switzerland. 2011.

8. Sechi LA, Lezcano I, Nunez N, Espim M, Duprè I, Pinna A, et al. Antibacterial activity of ozonized sunflower oil (Oleozon). J Appl Microbiol. 2001;90:27984 .

9. Krammer F. Ozone in the dental practice. Medical applications of ozone. Norwalk, CT: International Ozone Association, Pan American Committee;1983.p.258-65.

10. Das S. Application of ozone therapy in dentistry. Indian J Dent Adv. 2011;3(2):538-542.

11. Ajeti NN, Pustina-Krasniqi T, Apostolska S. The Effect of Gaseous Ozone in Infected Root Canal. Open Access Maced J Med Sci. 2018;6(2):389-396. https://doi.org/10.3889/oamjms.2018.102.

12. Huth KC, Quirling M, Maier S, Kamereck K, Alkhayer M, Paschos E, Welsch U, Miethke T, Brand K, Hickel R. Effectiveness of ozone against endodontopathogenic microorganisms in a root canal biofilm model. Int Endod J. 2009;42(1):3-13. https://doi.org/10.1111/j.1365-2591.2008.0146o.x.

13. Nagayoshi M, Fukuizumi T, Kitamura C, Yano J, Terashita M, Nishihara T. Efficacy of ozone on survival and permeability of oral microorganisms. Oral Microbiol Immunol. 2004;19:240-6.

14. Petrov GM, Kudriavtsev BP, Akulich II. The efficacy of using ozone preparations in the combined treatment of paranasal sinusitis. Voen Med Zh. 1996;317(12):26-8, 80 .

15. Daif ET. Role of intra-articular ozone gas injection in the management of internal derangement of the temporomandibular joint. Oral Surg Oral Med Oral Pathol Oral Radiol. 2012;113(6):e10-4. https://doi.org/10.1111/10.1016/j.tripleo.2011.08.0o6.

16. Kazancioglu HO, Kurklu E, Ezirganli S. Effects of ozone therapy on pain, swelling, and trismus following third molar surgery. Int J Oral Maxillofac Surg. 2014;43(5):644-8. doi: 10.1016/j.ijom.2013.11.006.

17. Seidler V, Linetskiy I, Hubálková H, Stanková H, Smucler R, Mazánek J. Ozone and its usage in general medicine and dentistry. A review article. Prague Med Rep. 2008;109(1):5-13.

18. Szymańska J. Evaluation of mycological contamination of dental unit waterlines. Ann Agric Environ Med. 2005;12:153-5.

19. Kohno S, Kawata T, Kaku M, Fuita T, Tsutsui K, Ohtani J, et al. Bactericidal effects of acidic electrolyzed water on the dental unit waterline. Jpn J Infect Dis. 2004;57:52-4.

20. Walker JT, Bradshaw DJ, Fulford MR, Marsh PD. Microbiological evaluation of a range of disinfectant products to control mixed species biofilm contamination in a laboratory model of a dental unit water system. Appl Environ Microbiol. 2003;69:332732.

21. Bocci V. Autohemotherapy after treatment of blood with ozone. A reappraisal. J Int Med Res. 1994;22(3):13144 .

22. Elvis AM, Ekta JS. Ozone therapy: a clinical review. J Nat Sci Biol Med. 2011;2(1):66-70.

23. Broadwater WT, Hoehn RC. Sensitivity of three selected bacterial species to ozone. Appl Microbiol. 1973;26(3):391-3.

24. Chang $\mathrm{H}$, Lynch E, Grootveld M. Oxidative consumption of oral biomolecules by therapeuticallyrelevant doses of ozone. Adv Chem Eng Sci. 2012;2:23845.

25. Werkmeister H. Subatmospheric $\mathrm{O}_{2} / \mathrm{O}_{3}$ treatment of therapy-resistant wounds and ulcerations. OzoNachrichten. 1985;4:53-9. 
26. Bocci VA. Tropospheric ozone toxicity vs. usefulness

of ozone therapy. Arch Med Res. 2007;38:265-7.

Source of support: Nil, Conflict of interest: None declared

Cite this article as:

Kumar V, Chandni. Ozone in Dentistry: A Review. Int Healthc Res J. 2021;5(3):RV1-RV5. https://doi.org/10.26440/IHRJ/0503.06416

AUTHOR AFFILIATIONS: (*Corresponding Author)

1. Department of Oral and Maxillofacial Surgery

2. Department of Periodontology and Oral Implantology (https://orcid.org/oooo-0oo2-8820-0204)

Desh Bhagat Dental College and Hospital, Mandi Gobindgarh

Contact corresponding author at: dr.vinitkathpalmds[at]gmail[dot]com 